\title{
APLIKASI UNTUK MENGENERATE DAN PENGIRIMAN SERTIFIKAT WEBINAR DI MASA PANDEMI CORONA VIRUS DISEASE 19
}

\author{
Lasmedi Afuan $^{* 1}$, Nurul Hidayat ${ }^{2}$, Siti Nurhayati ${ }^{3}$ \\ 1,2, Jurusan Informatika, Fakultas Teknik, Universitas Jenderal Soedirman, Indonesia \\ ${ }^{3}$ Jurusan Kesehatan Masyarakat, Fakultas Ilmu Kesehatan, Universitas Jenderal Soedirman, Indonesia

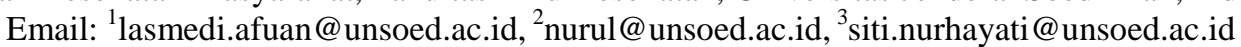 \\ *Penulis Korespondensi
}

(Naskah masuk: 29 April 2021, diterima untuk diterbitkan: 19 Juli 2021)

\begin{abstract}
Abstrak
Pandemi Coronavirus Disease (COVID-19) terjadi di lebih dari 200 negara termasuk Indonesia, telah mengubah kebiasaan masyarakat dalam berkomunikasi dan berinteraksi. Covid-19 memaksa masyarakat untuk berkomunikasi dan berinteraksi secara online dengan menggunakan platform seperti Zoom, Google-meet, Webex, dan platform lainnya. Salah satu sektor yang mengalami dampak yang mengharuskan berkomunikasi dan berinteraksi secara online adalah sektor pendidikan, hal tersebut bertujuan untuk mencegah penyebaran dan penularan Covid-19. Salah satu kegiatan di sektor pendidikan yang harus dilaksanakan secara online adalah seminar. Seminar yang dilaksanakan secara online di masa pandemi Covid-19 ini dikenal dengan sebutan Webinar. Pada webinar, pengelola webinar menghadapi permasalahan setelah pelaksanaan webinar yaitu bagaimana mengenerate dan mengirimkan sertifikat kepada peserta webinar secara massal. Penelitian ini telah mengembangkan aplikasi berbasis web yang diberi nama Cobinar. Cobinar merupakan aplikasi yang digunakan untuk membantu pengelola webinar dalam mengatasi permasalahan yang berkaitan generate dan pengiriman sertifikat massal kepada peserta webinar. Aplikasi Cobinar dikembangkan dengan menggunakan bahasa pemrograman PHP dan menggunakan Database Management System (DBMS) MySql. Sedangkan metode pengembangan perangkat lunak yang digunakan adalah Waterfall. Berdasarkan hasil uji coba, aplikasi Cobinar ini mampu mengenerate dan mengirimkan sertifikat ke peserta webinar dengan lebih efektif dan efisien, hal ini dapat dilihat dari hasil pengujian menggunakan User Acceptance Test (UAT) yang menyatakan bahwa 95 persen pengguna menyatakan bahwa aplikasi Cobinar mudah untuk dijalankan. Kontribusi utama dari penelitian ini adalah pengembangan sebuah aplikasi yang dapat digunakan oleh pengelola webinar untuk mengenerate dan mengirimkan sertifikat webinar kepada peserta.
\end{abstract}

Kata kunci : aplikasi, covid-19, cobinar, pendidikan, webinar, web.

\section{APPLICATION FOR GENERATE AND SENDING WEBINAR CERTIFICATES DURING THE CORONA VIRUS DISEASE PANDEMIC 19}

\begin{abstract}
The Coronavirus Disease (COVID-19) pandemic occurred in more than 200 countries, including Indonesia, which has changed people's habits in communicating and interacting. Covid-19 forces people to communicate and interact online using Zoom, Google-meet, Webex, and other platforms. One sector that has experienced the impact of communicating and interacting online is the education sector, which aims to prevent the spread and transmission of Covid-19. One of the activities in the education sector that must be carried out online is a conference. This conference, which was held online during the Covid-19 pandemic, is known as a Webinar. The webinar manager faced a problem after the webinar, namely, how to generate and send certificates to webinar participants. This research has developed a web-based application called Cobinar. Cobinar is an application used to assist webinar managers in overcoming problems related to generating and sending mass certificates to webinar participants. The Cobinar application was developed using the PHP programming language and using the MySql Database Management System (DBMS). While the software development method used is Waterfall. The Cobinar application can generate and send certificates to webinar participants more effectively and efficiently based on testing. It can be
\end{abstract}


seen from the results of testing using the User Acceptance Test (UAT), which states that 95 percent of users state that the Cobinar application is easy to operate. The main contribution of this research is the development of an application that webinar administrators can use to generate and send webinar certificates to participants.

Keywords : application, covid-19, cobinar, education, webinar, web.

\section{PENDAHULUAN}

Pada Desember 2019, dunia dikejutkan dengan terjadinya wabah virus Corona yang kemudian dikenal dengan sebutan Coronavirus Desease (Covid-19). Covid-19 pertama kali muncul di kota Wuhan, provinsi Hubei, Cina(Shi dkk., 2020). Covid-19 menyebar dengan cepat ke lebih dari 30 negara hingga 30 Januari 2020(Wilder-Smith \& Freedman, 2020). Covid-19 menyebar dengan cepat ke seluruh dunia, setiap hari data pasien yang terkena dan pasien yang meninggal Covid-19 terus bertambah(Khasanah, Pramudibyanto \& Widuroyekti, 2020), dengan kondisi penyebaran yang begitu cepat, Covid-19 telah diumumkan sebagai pandemic oleh World Health Organization (WHO)(Sohrabi $d k k$., 2020). Beragam upaya telah dilakukan oleh banyak Negara untuk mencegah penyebaran dan penularan Covid-19 diantaranya dengan melakukan karantina(Darmalaksana $d k k ., 2020$ ), penerapan social distancing(Darmalaksana $d k k$., 2020), dan penerapan protokol kesehatan Covid-19.

Kasus Covid-19 muncul pertama kali di Indonesia pada awal Maret 2020, secara resmi diumumkan oleh Bapak Presiden RI bahwa Covid-19 diidentifikasi pertama kali menular pada warga negara Indonesia yaitu anak dan ibu berumur 31 tahun (pasien 01) dan 64 tahun (pasien 02). Setelah dilakukan tracing, kasus pertama ini merupakan hasil dari interaksi antara warga negara Indonesia dengan warga negara Jepang di sebuah klub dansa.

Angka kematian akibat Covid-19 di Indonesia terus meningkat sejak diumumkan pertama kali(Khasanah, Pramudibyanto \& Widuroyekti, 2020). Hal tersebut dipengaruhi perubahan-perubahan dan pembaharuan kebijakan untuk diterapkan. Dalam upaya mencegah penyebaran dan penularan Covid-19 di Indonesia, pemerintah RI memutuskan untuk menerapkan kebijakan-kebijakan baru seperti penerapan Work From Home (WFH), School From Home (SFH), dan Ibadah di rumah.

Pada sektor pendidikan, melalui surat Edaran oleh Kementerian Pendidikan dan Kebudayaan Direktorat Pendidikan Tinggi No.1 Tahun 2020 tentang pencegahan penyebaran Covid-19 di Perguruan Tinggi, telah direalisasikan kebijakan baru yang menuntut dan menyarankan kepada seluruh perguruan tinggi di Indonesia untuk memulai pembelajaran jarak jauh (online), atau dalam arti lain para mahasiswa diharuskan untuk melakukan perkuliahan di rumah masing-masing. Tidak hanya perkuliahan saja yang dilakukan secara online, akan tetapi dengan adanya surat edaran tersebut, maka pelaksanaan seminar yang biasanya dilakukan secara tatap muka, harus dilaksanakan secara online. Teknologi informasi telah dimanfaatkan untuk membantu berbagai aktivitas manusia, berbagai sistem telah dikembangkan oleh para peneliti (Afuan, Ashari \& Suyanto, 2021), (Afuan \& Permadi, 2013), (Lidimilah \& Hermanto, 2018), (Jaya, 2018), (Muntohar, 2020), (Tiawan \& Afuan, 2020)(Pangestu $\&$ Afuan, 2021). Berdasarkan permasalahan yang telah dijelaskan, dengan adanya kebijakan baru tersebut, para pengelola berusaha untuk tetap melaksanakan seminar yang diselenggarakan secara online. Beberapa peneliti telah mengusulkan aplikasi yang membantu dalam pelaksanaan webinar (Durahman \& Noer, 2019), (Putra, Hanim \& Kartika, 2020), hanya saja aplikasi yang dikembangkan hanya sebatas pengelolaan pelaksanaan webinar saja tidak sampai proses pengelolaan sertifikat webinar. Permasalahan baru muncul bagi pengelola webinar ketika webinar sudah dilaksanakan, pengelola diharuskan membuat dan mengirimkan sertifikat (e-certificate) ke masingmasing peserta webinar. Hal ini tentu saja membutuhkan waktu dan tenaga bagi pengelola webinar. Untuk mengatasi permasalahan yang dihadapi oleh pengelola webinar, penelitian ini mengembangkan aplikasi yang dapat digunakan oleh pengelola webinar dalam mengenerate dan mengirimkan sertifikat secara massal ke peserta webinar.

\section{METODE PENELITIAN}

Ada beberapa tahapan yang telah dilakukan untuk mengembangkan aplikasi Cobinar yaitu (1) Tahapan pengumpulan data; (2) Tahapan pengembangan aplikasi; (3) Tahapan pengujian aplikasi. Pada tahapan pengumpulan data, ada dua metode yang digunakan dalam pengumpulan data yaitu wawancara dan observasi. Wawancara merupakan dialog antara dua orang atau lebih di mana terdapat narasumber yang akan diwawancarai dan pewawancara. Tujuan dari wawancara adalah mendapatkan informasi mengenai pertanyaanpertanyaan yang diajukan oleh pewawancara. Pada penelitian ini dilakukan wawancara dengan salah satu pengelola webinar. Sedangkan observasi merupakan suatu metode dalam mengumpulkan data melalui 
pengamatan secara langsung di lapangan. Dalam hal ini, peneliti memerlukan informasi mengenai cara kerja dari pelaksanaan webinar. Oleh karena itu perlu dilakukan observasi untuk mendapatkan data yang diperlukan. Tahapan selanjutnya adalah perancangan aplikasi. Perancangan aplikasi Cobinar menggunakan menggunakan metode Waterfall (Pressman, 2010). Pada metode Waterfall terdapat 5 tahapan, yaitu tahap requirements definition (analisis kebutuhan), system and software design (desain sistem), implementation and unit testing (penulisan kode program), integration and system testing (pengujian sistem), operation and maintenance (penerapan dan pemeliharaan). Metode Waterfall melakukan pendekatan secara sistematis dan berurutan seperti yang ditunjukkan pada Gambar 1 .

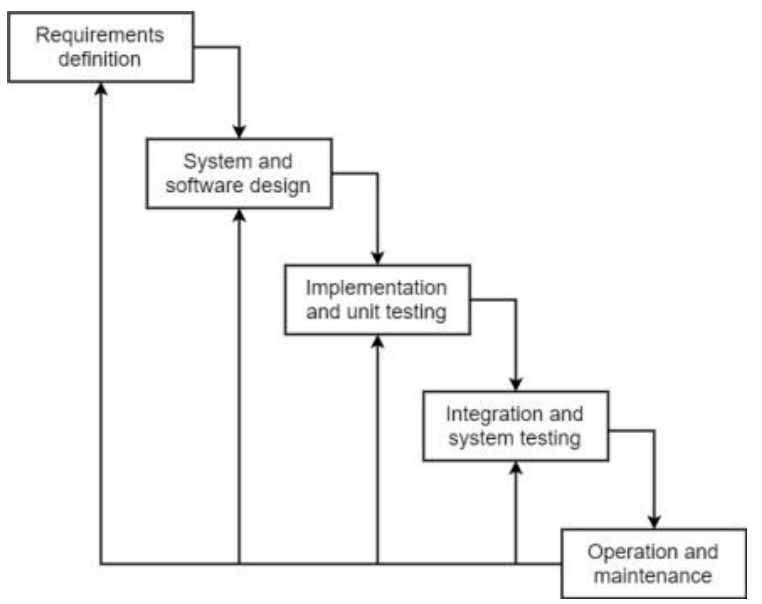

Gambar 1. Metode Waterfall(Pressman, 2010)

Tahap requirements definition atau analisis kebutuhan merupakan tahap pertama yang menjadi dasar proses pembuatan aplikasi. Tahap analisis dilakukan dengan cara wawancara dan observasi. Setelah dilakukan analisis maka akan terbentuk kebutuhan-kebutuhan pengguna atau user requirement.

Tahap system and software design atau desain sistem merupakan tahapan untuk menyusun data, aliran proses yang terjadi di dalam sistem, keterkaitan antar proses satu dengan lainnya berdasarkan analisis hasil kebutuhan pengguna. Pada tahap ini akan menghasilkan dua desain, yaitu desain data dan desain antarmuka. Desain data akan menghasilkan DFD (Data Flow Diagram) dan ERD (Entity Relational Diagram), sedangkan desain antarmuka akan menghasilkan desain antarmuka yang akan diterapkan ke aplikasi. Tahap implementation and unit testing atau penulisan kode program merupakan tahap penerjemahan desain sistem yang telah dibuat ke dalam bentuk perintah-perintah yang dimengerti komputer menggunakan bahasa pemrograman dan basis data tertentu. Tahap ini merupakan implementasi dari tahap desain sistem. Aplikasi Cobinar ini menggunakan bahasa pemrograman PHP dan basis data $M y S Q L$.

Tahap integration and system testing atau pengujian sistem merupakan tahap untuk menguji sistem yang dibuat untuk mengetahui kekurangan pada sistem sebelum digunakan. Pengujian ini dilakukan oleh pembuat sistem dan pengguna sistem. Apabila ketika pengujian ditemukan kesalahan maka akan disempurnakan kembali oleh pengembang sampai aplikasi sesuai dengan kebutuhan pengguna. Adapun metode pengujian yang akan digunakan adalah pengujian BlackBox.

Tahap operation and maintenance atau penerapan dan pemeliharaan merupakan tahap menerapkan sistem yang telah dibuat dan diuji ke dalam lingkungan instansi. Pemeliharaan dilakukan agar penggunaan dari sistem dapat terus optimal dan meminimalkan kegagalan sistem. Perawatan dapat dilakukan secara berkala terhadap sistem, basis data, dan komponen pendukungnya. Perawatan juga dapat dilakukan dengan membuat petunjuk penggunaan.

\section{HASIL DAN PEMBAHASAN}

Pada tahapan ini akan membahas mengenai tahapan-tahapan yang dilakukan untuk mengembangkan aplikasi Cobinar berdasarkan tahapan-tahapan yang telah dijelaskan pada bagian 2 . Tahap requirements definition atau tahap analisis dilakukan untuk menjelaskan secara rinci dan menggambarkan aplikasi yang dibangun agar efektif serta memenuhi kebutuhan pengguna. Pada pembuatan aplikasi Cobinar, untuk membentuk user requirement digunakan beberapa metode, yaitu wawancara dan observasi. Pada tahap wawancara dan observasi diperoleh siapa saja pengguna dari aplikasi Cobinar yaitu admin. Pengguna admin merupakan user yang secara penuh mengelola webinar. Tahap selanjutnya dalam perancangan sistem adalah mengidentifikasi kebutuhan masing-masing pengguna. Seperti yang dikemukakan sebelumnya, bahwa dalam pembuatan sistem ini digunakan metode pengumpulan data wawancara dan observasi untuk mengetahui kebutuhan masing-masing pengguna yang perlu diterapkan pada aplikasi. Daftar kebutuhan pengguna aplikasi disajikan pada Tabel 1 .

Tabel 1. Daftar kebutuhan Admin

\begin{tabular}{lll}
\hline No & \multicolumn{1}{c}{ Kebutuhan } & \multicolumn{1}{c}{ Kode } \\
\hline 1 & $\begin{array}{l}\text { Admin dapat mengelola } \\
\text { jadwal webinar }\end{array}$ & [UR-A-01] \\
1 & $\begin{array}{l}\text { Admin dapat melakukan } \\
\text { set email sender }\end{array}$ & [UR-A-02] \\
2 & $\begin{array}{l}\text { Admin dapat mengelola } \\
\text { template sertifikat }\end{array}$ & [UR-A-03] \\
\hline
\end{tabular}


738 Jurnal Teknologi Informasi dan Ilmu Komputer (JTIIK), Vol. 8, No. 4, April 2021, hlm. 735-744

\begin{tabular}{|c|c|c|}
\hline No & Kebutuhan & Kode \\
\hline 3 & $\begin{array}{l}\text { Admin bisa mengelola } \\
\text { data peserta webinar }\end{array}$ & [UR-A-04] \\
\hline 4 & $\begin{array}{l}\text { Admin bisa mengenerate } \\
\text { dan mengirimkan } \\
\text { sertifikat secara massal } \\
\text { ke peserta webinar }\end{array}$ & [UR-A-05] \\
\hline 5 & $\begin{array}{lr}\text { Admin } & \text { dapat } \\
\text { mengirimkan } & \text { pesan } \\
\text { (broadcast) } & \text { kepada } \\
\text { peserta webinar } & \end{array}$ & [UR-A-06] \\
\hline 6 & $\begin{array}{l}\text { Admin dapat melakukan } \\
\text { perubahan kata sandi }\end{array}$ & [UR-A-07] \\
\hline 7 & $\begin{array}{l}\text { Admin dapat mengelola } \\
\text { pengguna aplikasi }\end{array}$ & [UR-A-08] \\
\hline 8 & $\begin{array}{l}\text { Admin dapat } \\
\text { mencadangkan basis data } \\
\text { aplikasi }\end{array}$ & [UR-A-09] \\
\hline
\end{tabular}

Hasil analisis yang telah dilakukan terhadap pengguna, aplikasi yang dikembangkan hanya memiliki antar muka untuk pengguna admin saja. Dari uraian kebutuhan pengguna di atas dapat disimpulkan apa saja fasilitas yang dibutuhkan oleh aplikasi. Kebutuhan fungsional mendeskripsikan layanan, fasilitas atau fungsi yang disediakan atau diberikan oleh sistem kepada penggunanya. Analisis dari fasilitas-fasilitas yang dibutuhkan oleh aplikasi Cobinar disajikan pada Tabel 2.

Tabel 2. Kebutuhan fungsional

\begin{tabular}{|c|c|c|}
\hline No & Kebutuhan & Kode \\
\hline 1 & $\begin{array}{l}\text { Aplikasi memberikan hak akses } \\
\text { kepada pengguna melalui form } \\
\text { log in di mana data yang } \\
\text { dimasukkan berupa username } \\
\text { dan password }\end{array}$ & [SR-01] \\
\hline 2 & $\begin{array}{l}\text { Aplikasi memberikan hak akses } \\
\text { kepada pengguna melalui form } \\
\text { log in di mana data yang } \\
\text { dimasukkan berupa username } \\
\text { dan password }\end{array}$ & [SR-02] \\
\hline 3 & $\begin{array}{l}\text { Aplikasi memberikan pesan } \\
\text { kesalahan jika data login yang di } \\
\text { masukan pada saat proses } \log \text { in } \\
\text { tidak sesuai }\end{array}$ & [SR-03] \\
\hline 4 & $\begin{array}{l}\text { Aplikasi menyediakan form } \\
\text { untuk memasukkan jadwal } \\
\text { webinar }\end{array}$ & [SR-04] \\
\hline 5 & $\begin{array}{l}\text { Aplikasi memiliki fasilitas untuk } \\
\text { mengubah jadwal webinar }\end{array}$ & [SR-05] \\
\hline 6 & $\begin{array}{l}\text { Aplikasi memiliki fasilitas untuk } \\
\text { menghapus jadwal webinar }\end{array}$ & [SR-06] \\
\hline 7 & $\begin{array}{l}\text { Aplikasi memiliki fasilitas untuk } \\
\text { menampilkan jadwal webinar }\end{array}$ & [SR-07] \\
\hline 8 & $\begin{array}{l}\text { Aplikasi memiliki fasilitas ubah } \\
\text { email sender }\end{array}$ & [SR-08] \\
\hline 9 & $\begin{array}{l}\text { Aplikasi memiliki fasilitas untuk } \\
\text { menampilkan daftar email } \\
\text { sender }\end{array}$ & [SR-09] \\
\hline 10 & $\begin{array}{l}\text { Aplikasi menyediakan fasilitas } \\
\text { pengelolaan template sertifikat }\end{array}$ & [SR-10] \\
\hline 11 & $\begin{array}{l}\text { Aplikasi menyediakan form } \\
\text { untuk menambah data peserta }\end{array}$ & [SR-11] \\
\hline 12 & $\begin{array}{l}\text { Aplikasi menyediakan fasilitas } \\
\text { untuk mengubah data peserta }\end{array}$ & [SR-12] \\
\hline 13 & Aplikasi menyediakan fasilitas & [SR-13] \\
\hline
\end{tabular}

\begin{tabular}{|c|c|c|}
\hline No & Kebutuhan & Kode \\
\hline 14 & $\begin{array}{l}\text { untuk menampilkan data peserta } \\
\text { Aplikasi menyediakan fasilitas } \\
\text { untuk mengenerate sertifikat }\end{array}$ & [SR-14] \\
\hline 15 & $\begin{array}{l}\text { Aplikasi menyediakan fasilitas } \\
\text { untuk mengirimkan sertifikat }\end{array}$ & [SR-15] \\
\hline 16 & $\begin{array}{l}\text { Aplikasi menyediakan fasilitas } \\
\text { untuk broadcast pesan }\end{array}$ & [SR-16] \\
\hline 17 & $\begin{array}{l}\text { Aplikasi menyediakan fasilitas } \\
\text { untuk mengubah sandi admin }\end{array}$ & [SR-17] \\
\hline 18 & $\begin{array}{l}\text { Aplikasi menyediakan form } \\
\text { untuk tambah pengguna aplikasi }\end{array}$ & [SR-18] \\
\hline 19 & $\begin{array}{l}\text { Aplikasi menyediakan form } \\
\text { untuk mengubah data pengguna } \\
\text { aplikasi }\end{array}$ & [SR-19] \\
\hline 20 & $\begin{array}{l}\text { Aplikasi menyediakan fasilitas } \\
\text { untuk menghapus data pengguna } \\
\text { aplikasi }\end{array}$ & [SR-20] \\
\hline 21 & $\begin{array}{l}\text { Aplikasi menyediakan tampilan } \\
\text { untuk melihat data pengguna }\end{array}$ & [SR-21] \\
\hline 22 & $\begin{array}{l}\text { Aplikasi menyediakan fasilitas } \\
\text { untuk logout }\end{array}$ & [SR-22] \\
\hline 23 & $\begin{array}{l}\text { Aplikasi menyediakan pesan } \\
\text { bahwa pengguna berhasil logout }\end{array}$ & [SR-23] \\
\hline
\end{tabular}

Kebutuhan non fungsional mendeskripsikan sekumpulan batasan, karakteristik dan properti pada sistem, baik dalam lingkungan pengembang maupun operasional, atau atribut kualitas yang harus dipenuhi oleh sistem. Kebutuhan non fungsional aplikasi Cobinar, seperti Web browser, koneksi internet, dan sistem operasi. Tahap System and Software Design atau tahap desain mengacu pada kebutuhan pengguna dari tahap analisis yang sudah dibuat. Desain aplikasi akan dibuat dengan menggunakan Data Flow Diagram (DFD) dan Entity Relationship Diagram (ERD). Kesatuan luar yang terlibat dalam aplikasi Cobinar yaitu Admin (pengelola webinar). Kesatuan luar ini merupakan kesatuan (entity) di luar aplikasi, karena di luar bagian pengolahan data. Kesatuan ini merupakan sumber arus data ke aplikasi informasi serta tujuan penerima arus data hasil dari proses aplikasi, sehingga merupakan kesatuan di luar aplikasi. Input dan output yang terlibat dengan kesatuan luar pada aplikasi Cobinar disajikan pada Tabel 3.

Tabel 3. Identifikasi input dan output

\begin{tabular}{cll}
\hline External Entity & \multicolumn{1}{c}{ Input } & \multicolumn{1}{c}{ Output } \\
\hline Admin & Data Peserta & Informasi Peserta \\
& Data Login & Informasi Login \\
& Data Email Sender & Informasi Email \\
& Data Template & Sender \\
& sertifikat & Informasi \\
& Data Pesan & Template \\
& (broadcast) & Sertifikat \\
& Data Sandi & Informasi Pesan \\
& Data pengguna & Informasi Sandi \\
& & Informasi \\
& & Pengguna \\
\hline
\end{tabular}




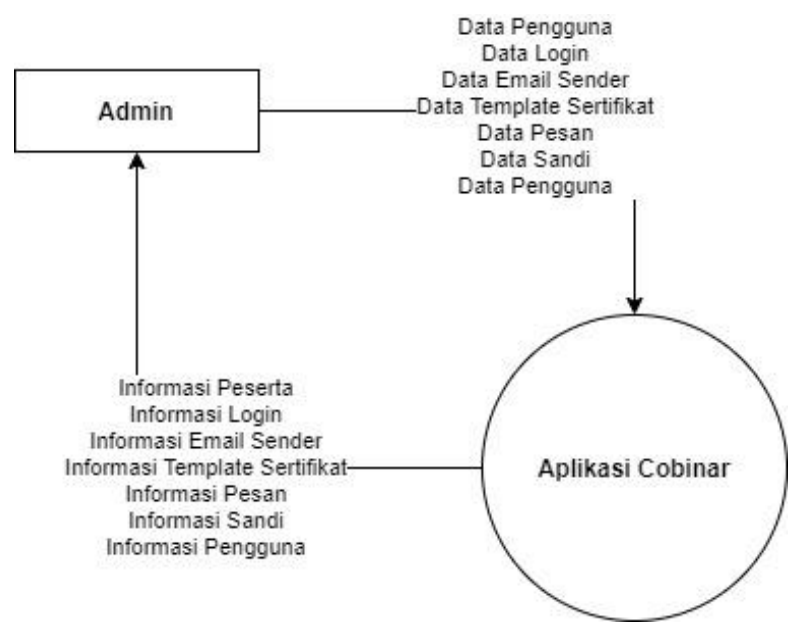

Gambar 2. DFD Level 0

Gambar 2 menampilkan DFD Level 0 dari aplikasi Cobinar, Gambar 2 menunjukkan bahwa aplikasi Cobinar memiliki satu entitas yaitu admin. Aliran data yang masuk ke dalam aplikasi adalah data pengguna, data login, data email sender, data template sertifikat, data pesan, data sandi, dan data pengguna. Kamus data bagi aplikasi Cobinar dapat dilihat pada Tabel 4.

Tabel 4. Kamus data

\begin{tabular}{|c|c|c|}
\hline Nama & Pengertian & Entitas \\
\hline Data Peserta & $\begin{array}{l}\text { Data peserta berisi } \\
\text { data mengenai } \\
\text { peserta yang } \\
\text { mengikuti webinar }\end{array}$ & Admin \\
\hline Data Login & $\begin{array}{l}\text { Data Login berisi } \\
\text { nama pengguna dan } \\
\text { sandi pengguna } \\
\text { yang digunakan } \\
\text { untuk login ke } \\
\text { dalam aplikasi } \\
\text { Cobinar }\end{array}$ & Admin \\
\hline Data Email Sender & $\begin{array}{l}\text { Data email sender } \\
\text { berisi data email } \\
\text { yang digunakan } \\
\text { untuk mengirimkan } \\
\text { sertifikat ke peserta } \\
\text { webinar }\end{array}$ & Admin \\
\hline $\begin{array}{l}\text { Data Template } \\
\text { sertifikat }\end{array}$ & $\begin{array}{l}\text { Data template } \\
\text { sertifikat dari } \\
\text { webinar yang } \\
\text { diselenggarakan }\end{array}$ & Admin \\
\hline $\begin{array}{l}\text { Data Pesan } \\
\text { (broadcast) }\end{array}$ & $\begin{array}{l}\text { Data pesan yang } \\
\text { dikirimkan ke } \\
\text { peserta webinar }\end{array}$ & Admin \\
\hline Data Sandi & $\begin{array}{l}\text { Data sandi berisi } \\
\text { data sandi pengguna }\end{array}$ & Admin \\
\hline Data pengguna & $\begin{array}{l}\text { Data pengguna } \\
\text { berisi data pengguna } \\
\text { dari aplikasi Cobinar }\end{array}$ & Admin \\
\hline
\end{tabular}

Pada Gambar 5 menampilkan ERD dari aplikasi Cobinar.
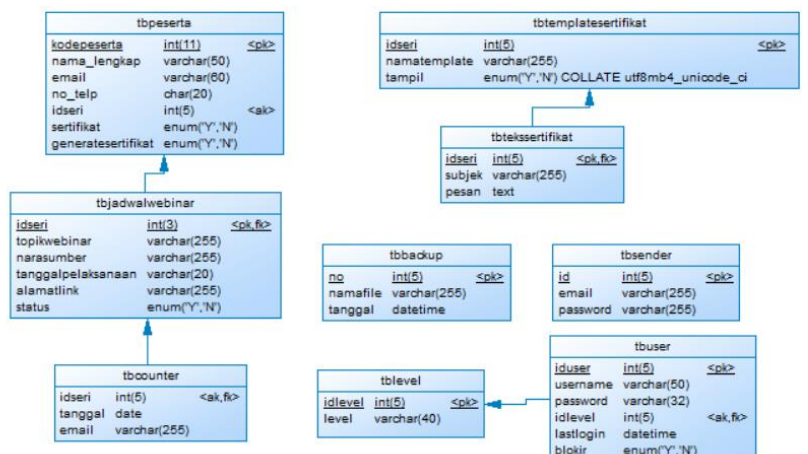

Gambar 3. Entity Relationship Diagram Aplikasi Cobinar

Pada Gambar 3 terdapat 9 entitas yang ada didalam aplikasi Cobinar antara lain entitas tbpesertam tbjadwalwebinar, tbcounter, tbtemplatesertifikat, tbbackup, tblevel, tbsender, tbuser. ERD pada Gambar 3 digunakan sebagai dasar untuk membuat tabel basisdata pada aplikasi Cobinar. Pada gambar 4 menunjukkan halaman awal dari aplikasi Cobinar. Pada halaman awal merupakan halaman login dari aplikasi Cobinar, untuk masuk ke dalam aplikasi, pengguna diharuskan memasukkan nama pengguna dan kata sandi. Gambar 4 merupakan implementasi dari requirement aplikasi [SR-01].

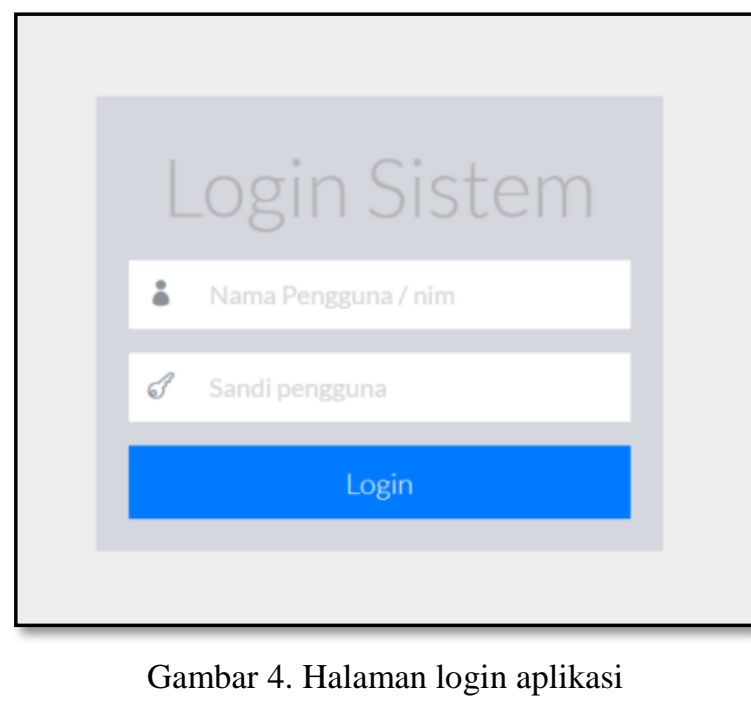

Pada Gambar 4, jika pengguna memasukkan nama pengguna dan sandi pengguna dengan benar maka pengguna dapat masuk ke halaman utama dari aplikasi Cobinar. Tampilan halaman utama dari aplikasi Cobinar ditunjukkan pada Gambar 4. 


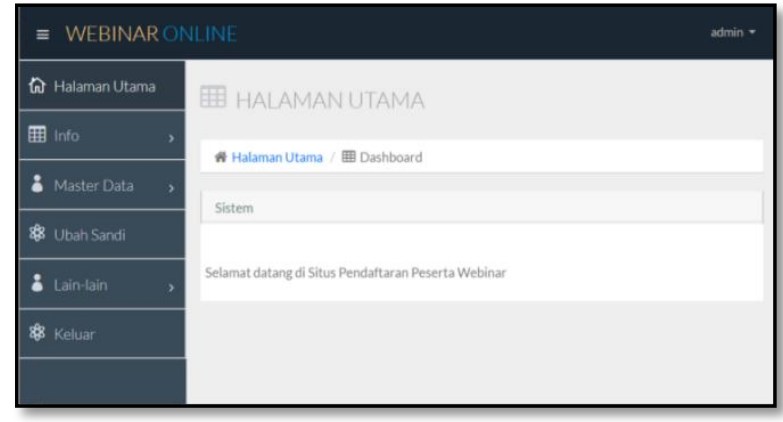

Gambar 5. Halaman utama aplikasi

Pada Gambar 5 terdapat beberapa menu yang dapat digunakan oleh pengelola webinar, menu tersebut yaitu info, master data, ubah sandi, dan menu lain-lain. Jika menu info di klik, maka akan menampilkan sub menu jadwal webinar. Halaman jadwal webinar seperti ditampilkan pada Gambar 6. Pada halaman jadwal webinar admin dapat melakukan pengelolaan jadwal webinar dengan memasukkan topik webinar, narasumber, tanggal pelaksanaan, dan alamat link dari platform yang digunakan pada saat pelaksanaan webinar. Halaman jadwal webinar ini merupakan implementasi dari requirement aplikasi [SR-07].

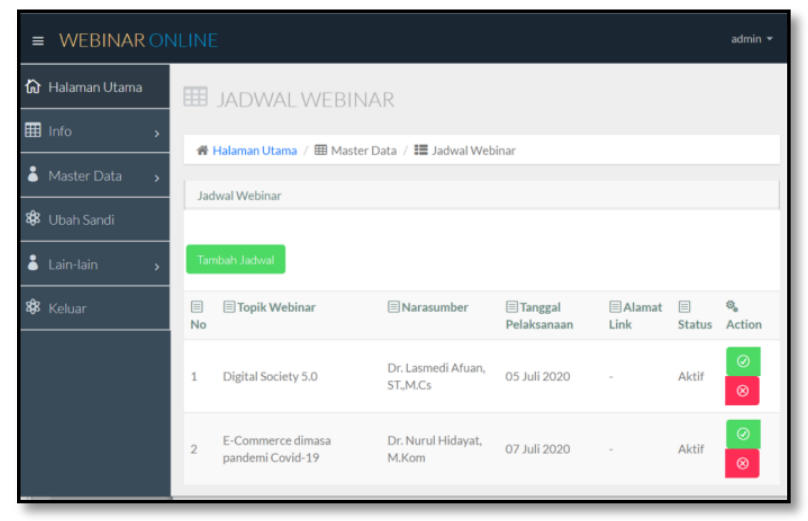

Gambar 6. Halaman jadwal webinar

Untuk dapat mengirimkan email ke peserta, pada aplikasi Cobinar harus dilakukan pengaturan email sender. Email sender berfungsi untuk mengidentifikasi alamat email dari pengirim sertifikat atau pengirim pesan. Gambar 7 menunjukkan halaman untuk mengatur email sender pada aplikasi Cobinar. Halaman email sender merupakan implementasi dari requirement [SR-09].

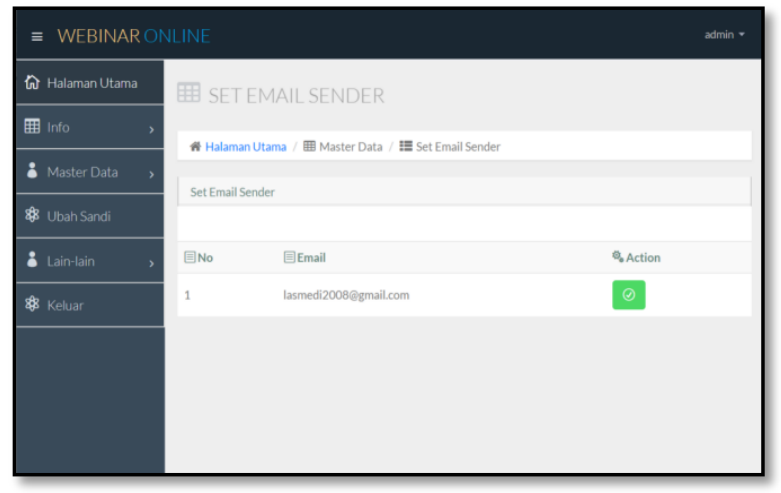

Gambar 7. Halaman email sender

Admin dapat mengirimkan sertifikat ke peserta dengan menggunakan template yang sudah diunggah untuk setiap kegiatan webinar. Tampilan halaman pengelolaan template sertifikat dapat dilihat pada Gambar 8. Admin dapat mengunggah template sertifikat dengan menekan tombol "Upload template sertifikat". Halaman template sertifikat merupakan implementasi dari hasil analisis kebutuhan aplikasi yaitu [SR-10].

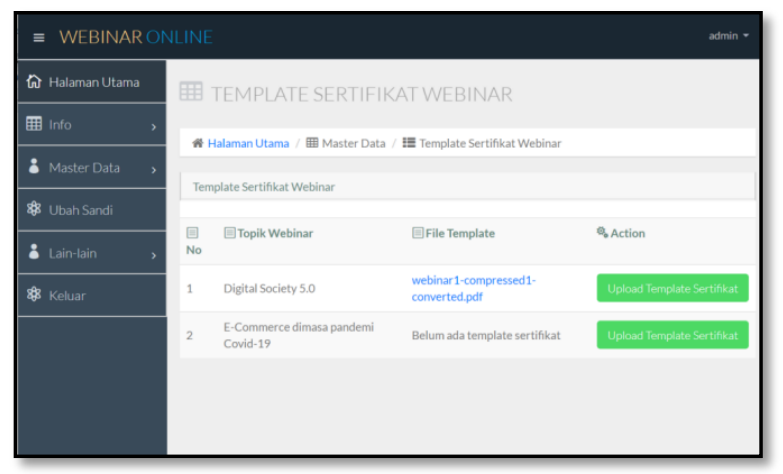

Gambar 8. Halaman template sertifikat

Selanjutnya, menu halaman pengelolaan daftar peserta webinar ditunjukkan pada Gambar 9, untuk melihat secara lengkap daftar peserta untuk setiap webinar, admin dapat menekan tombol "detail peserta webinar". Halaman daftar peserta merupakan implementasi dari analisis requirement [SR-13].

Gambar 10 menampilkan detail peserta yang mengikuti kegiatan webinar berdasarkan topik dari webinar. Pada halaman detail peserta webinar, admin dapat melakukan pengelolaan data peserta seperti proses tambah, ubah, dan hapus data peserta. Selain itu, admin juga dapat melihat status dari pengiriman sertifikat peserta yang sudah dikirim atau belum dikirim. 


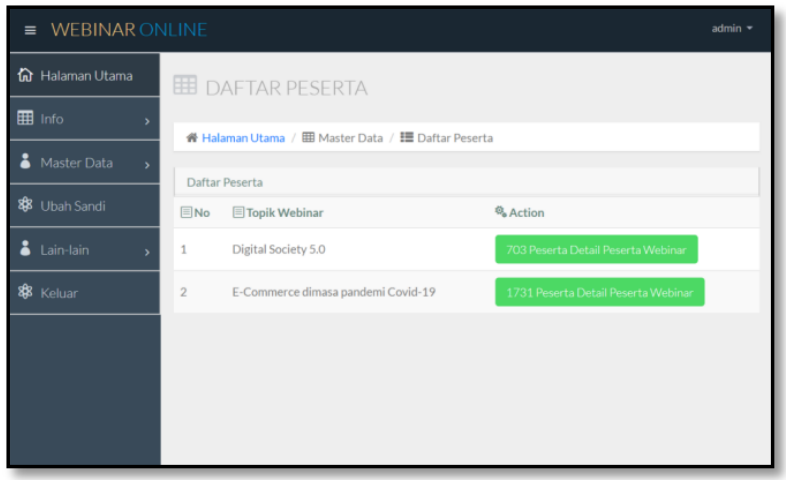

Gambar 9. Halaman daftar peserta

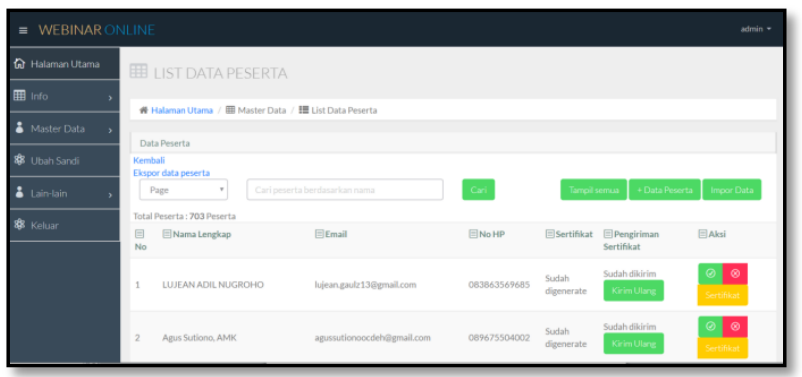

Gambar 10. Halaman detail peserta webinar

Halaman yang paling penting dalam aplikasi Cobinar adalah halaman untuk mengenerate dan mengirimkan sertifikat ke peserta webinar. Gambar 11 merupakan halaman untuk mengenerate dan mengirimkan sertifikat ke peserta. Untuk mengenerate, admin dapat melakukan dengan menekan tombol "generate sertifikat", dan untuk mengirimkan sertifikat, admin dapat menekan tombol "kirim sertifikat". Pengiriman sertifikat dilakukan secara otomatis dan kirim ke email setiap peserta. Gambar 11 merupakan implementasi dari requirement [SR-14] dan [SR-15].

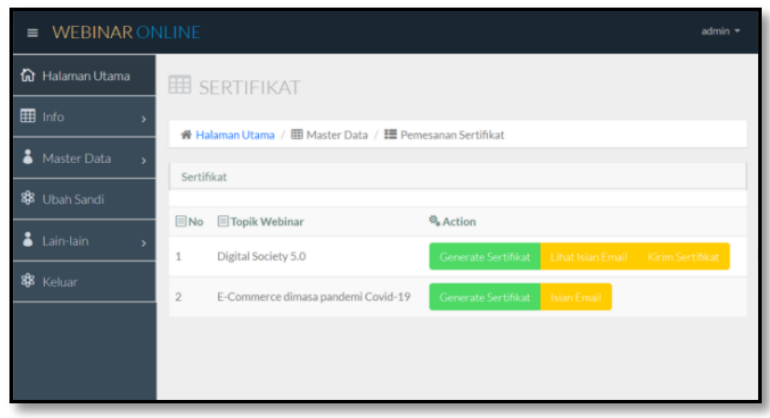

Gambar 11. Halaman generate dan pengiriman sertifikat

Untuk mengingatkan atau memberikan informasi kegiatan webinar, aplikasi Cobinar juga menyediakan fasilitas untuk mengirimkan pesan ke peserta, fasilitas tersebut dapat dilihat pada Gambar 12.

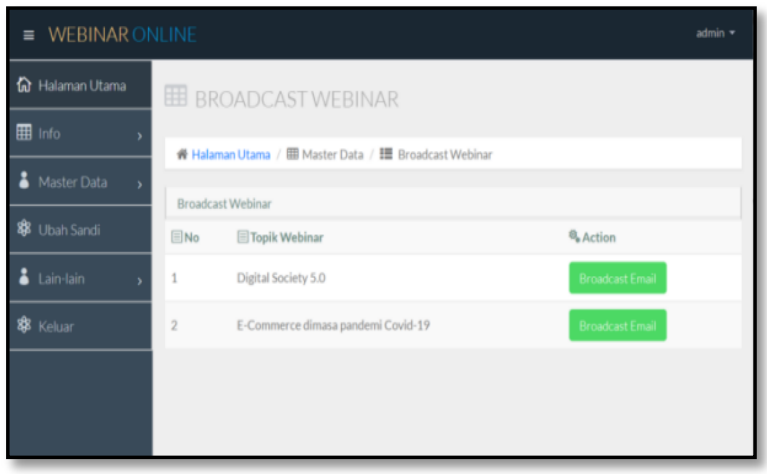

Gambar 12. Broadcast pesan webinar

Aplikasi Cobinar juga menyediakan halaman untuk pengelolaan data pengguna seperti ditampilkan pada Gambar 13. Pada halaman data pengguna, admin dapat melakukan proses tambah, ubah, dan hapus data pengguna. Halaman data pengguna ini merupakan implementasi dari [SR-18], [SR-19], [SR-20], dan [SR-21].

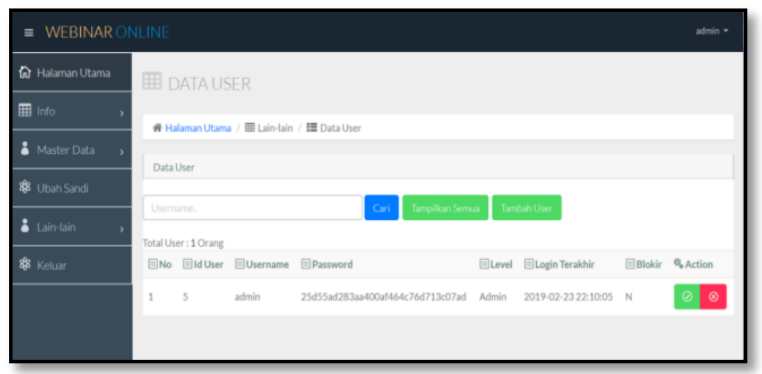

Gambar 13. Halaman data pengguna aplikasi

\section{Pengujian Aplikasi}

Pengujian ini dilakukan untuk melihat kinerja dari aplikasi yang telah dikembangkan. Pengujian aplikasi menggunakan metode BlackBox Testing dan penggunaan Mean Opinion Score (MOS) untuk melihat pendapat pengguna mengenai aplikasi Cobinar. BlackBox Testing merupakan metode pengujian perangkat lunak yang digunakan untuk menguji perangkat lunak tanpa mengetahui struktur internal program atau hanya mengamati fungsional dan eksekusi dari software. Hasil BlackBox testing dapat dilihat pada Tabel 5.

Tabel 5. Hasil BlackBox Testing

\begin{tabular}{clc}
\hline No & Fungsi yang diuji & \multicolumn{1}{c}{ Luaran yang diharapkan } \\
\hline 1. & $\begin{array}{l}\text { Halaman login } \\
\text { aplikasi }\end{array}$ & Nama dan password pengguna \\
2. & $\begin{array}{l}\text { Halaman utama } \\
\text { aplikasi }\end{array}$ & $\begin{array}{l}\text { Menampilkan halaman utama dari } \\
\text { aplikasi Cobinar }\end{array}$ \\
3. & $\begin{array}{l}\text { Halaman jadwal } \\
\text { webinar }\end{array}$ & $\begin{array}{l}\text { Menampilkan jadwal webinar dan } \\
\text { dapat digunakan untuk mengelola }\end{array}$ \\
\hline
\end{tabular}




\begin{tabular}{|c|c|c|}
\hline No & Fungsi yang diuji & Luaran yang diharapkan \\
\hline 4. & $\begin{array}{l}\text { Halaman email } \\
\text { sender }\end{array}$ & $\begin{array}{l}\text { jadwal webinar } \\
\text { Menampilkan email sender }\end{array}$ \\
\hline 5. & $\begin{array}{l}\text { Halaman template } \\
\text { sertifikat }\end{array}$ & $\begin{array}{l}\text { Menampilkan halaman } \\
\text { pengelolaan template sertifikat }\end{array}$ \\
\hline 6. & $\begin{array}{l}\text { Halaman daftar } \\
\text { peserta }\end{array}$ & $\begin{array}{l}\text { Menampilkan halaman daftar } \\
\text { peserta webinar }\end{array}$ \\
\hline 7. & $\begin{array}{l}\text { Halaman detail } \\
\text { peserta webinar }\end{array}$ & $\begin{array}{l}\text { Menampilkan halaman } \\
\text { pengelolaan peserta webinar }\end{array}$ \\
\hline 8. & $\begin{array}{l}\text { Halaman generate } \\
\text { dan pengiriman } \\
\text { sertifikat }\end{array}$ & $\begin{array}{l}\text { Menampilkan halaman generate } \\
\text { dan pengiriman sertifikat }\end{array}$ \\
\hline 9. & $\begin{array}{l}\text { Broadcast pesan } \\
\text { webinar }\end{array}$ & $\begin{array}{l}\text { Menampilkan } \\
\text { pengelolaan broadcast } \\
\text { webinar }\end{array}$ \\
\hline 10. & $\begin{array}{l}\text { Halaman data } \\
\text { pengguna aplikasi }\end{array}$ & $\begin{array}{l}\text { Menampilkan halaman } \\
\text { pengelolaan pengguna aplikasi }\end{array}$ \\
\hline
\end{tabular}

Tahap pengujian selanjutnya, menggunakan uji Mean Opinion Score (MOS) MOS adalah salah satu metode yang dapat digunakan untuk mengukur kualitas dan kinerja dari aplikasi atau sistem yang telah dikembangkan. Pengukuran MOS dilakukan dengan meminta kepada responden untuk menjawab beberapa pertanyaan setelah responden mencoba menggunakan sistem. Responden diminta untuk memberikan nilai pada rentang angka 1 sampai dengan 4. Di mana semakin besar angka yang dipilih menyatakan nilai yang terbaik. Kemudian dihitung rata-rata penilaian dari seluruh responden sehingga diperoleh nilai Mean Opinion Score dari sistem tersebut. Untuk pengujian MOS yang dilakukan berbasis user acceptance test (UAT). UAT ini dilakukan oleh 5 responden dengan 10 pertanyaan terkait sistem yang dibangun penulis dengan memberikan bobot penilaian tersebut dapat dilihat pada Tabel 6.

Hasil analisis dari pengujian yang telah dilakukan dengan menggunakan UAT, diperoleh nilai Mean Opinion (MO) yang disajikan dalam persentase sebagai berikut:

a) $95 \%$ responden menyatakan aplikasi Cobinar mudah dijalankan

b) $90 \%$ responden menyatakan tampilan dari aplikasi Cobinar mudah digunakan dan dipahami

c) $85 \%$ responden menyatakan tampilan (user interface) dari aplikasi Cobinar interaktif

d) $95 \%$ responden menyatakan aplikasi Cobinar sangat membantu masyarakat

e) $70 \%$ responden menyatakan respons waktu mengakses fasilitas tiap aplikasi Cobinar berlangsung cepat dan stabil

\section{KESIMPULAN}

Penelitian ini telah mengembangkan sebuah aplikasi yang telah digunakan untuk membantu pengelola webinar untuk mengenerate dan mengirimkan sertifikat secara massal ke peserta webinar, aplikasi tersebut diberi nama Cobinar.

Tabel 1. Tabel Hasil Survei Pengujian Sistem

\begin{tabular}{|c|c|c|c|c|c|}
\hline NO & Pertanyaan & SS & $\mathbf{S}$ & $\begin{array}{l}\mathbf{K} \\
\mathbf{S}\end{array}$ & $\begin{array}{l}\mathbf{T} \\
\mathbf{S}\end{array}$ \\
\hline 1. & $\begin{array}{l}\text { Aplikasi Cobinar mudah } \\
\text { dijalankan }\end{array}$ & 4 & 1 & & \\
\hline 2. & $\begin{array}{l}\text { Tampilan dari aplikasi } \\
\text { Cobinar mudah } \\
\text { digunakan dan dipahami }\end{array}$ & 3 & 2 & & \\
\hline 3. & $\begin{array}{l}\text { Tampilan (user interface) } \\
\text { dari aplikasi Cobinar } \\
\text { interaktif }\end{array}$ & 2 & 3 & & \\
\hline 4. & $\begin{array}{l}\text { Aplikasi Cobinar sangat } \\
\text { membantu masyarakat }\end{array}$ & 4 & 1 & & \\
\hline 5. & $\begin{array}{l}\text { Respons waktu } \\
\text { mengakses fasilitas tiap } \\
\text { sistem berlangsung cepat } \\
\text { dan stabil }\end{array}$ & 1 & 2 & 2 & \\
\hline 6. & $\begin{array}{l}\text { Aplikasi Cobinar } \\
\text { menampilkan data yang } \\
\text { sesuai }\end{array}$ & 1 & 4 & & \\
\hline 7. & $\begin{array}{l}\text { Aplikasi Cobinar } \\
\text { menghasilkan informasi } \\
\text { yang terbaru dengan tepat } \\
\text { waktu }\end{array}$ & 3 & 2 & & \\
\hline 8. & $\begin{array}{l}\text { fasilitas pada sistem } \\
\text { Aplikasi Cobinar sudah } \\
\text { lengkap }\end{array}$ & & 2 & 3 & \\
\hline 9. & $\begin{array}{l}\text { Tidak pernah mengalami } \\
\text { error/gangguan saat } \\
\text { menjalankan sistem }\end{array}$ & 2 & 2 & 1 & \\
\hline 10. & $\begin{array}{l}\text { Informasi pada aplikasi } \\
\text { Cobinar mudah dipahami }\end{array}$ & 3 & 2 & & \\
\hline
\end{tabular}

Pada aplikasi Cobinar memiliki beberapa fasilitas yang dapat digunakan oleh pengelola webinar antara lain mengelola jadwal webinar, melakukan set email sender, mengelola template sertifikat, mengelola data peserta webinar, mengenerate dan mengirimkan sertifikat secara massal ke peserta webinar, mengirimkan pesan (broadcast) kepada peserta webinar, melakukan perubahan kata sandi, mengelola pengguna aplikasi, dan mencadangkan basis data aplikasi

\section{UCAPAN TERIMA KASIH}

Peneliti mengucapkan terima kasih kepada LPPM Universitas Jenderal Soedirman atas pendanaan penelitian melalui skim Penelitian Peningkatan kompetensi. Selain itu juga, peneliti juga mengucapkan terima kasih kepada pihak-pihak yang telah membantu dalam pelaksanaan penelitian.

\section{DAFTAR PUSTAKA}

AFUAN, L., ASHARI, A. \& SUYANTO, Y. (2021) "A New Approach in Query Expansion Methods for Improving Information Retrieval," JUITA: Jurnal Informatika, 9(1), hal. 93-103.

AFUAN, L. \& PERMADI, I. (2013) "Rancang 
Bangun Sistem Infomasi Laboratorium (SILAB) Berbasis WEB Di Teknik Informatika UNSOED," Prosiding SNST Fakultas Teknik, 1(1), hal. 26-32.

DARMALAKSANA, W. DKK. (2020) "Analisis Pembelajaran Online Masa WFH Pandemic Covid-19 sebagai Tantangan Pemimpin Digital Abad 21," Karya Tulis Ilmiah (KTI) Masa Work From Home (WFH) Covid-19 UIN Sunan Gunung Djati Bandung Tahun 2020, 1(1), hal. 1-12.

DURAHMAN, N. \& NOER, Z. M. (2019) “Aplikasi Seminar Online (Webinar) Untuk Pembinaan Wirausaha Baru," Jurnal Manajemen Informatika, 6(2), hal. 111-120.

JAYA, T. S. (2018) "Pengujian Aplikasi dengan Metode Blackbox Testing Boundary Value Analysis (Studi Kasus: Kantor Digital Politeknik Negeri Lampung)," Jurnal Pengembangan IT (JPIT, 03(02), hal. 45-48.

KHASANAH, D. R. A. U., PRAMUDIBYANTO, H. \& WIDUROYEKTI, B. (2020) "Pendidikan Dalam Masa Pandemi Covid-19," Jurnal Sinestesia, 10(1), hal. 41-48. Tersedia pada: https://sinestesia.pustaka.my.id/journal/article /view/44.

LIDIMILAH, L. F. \& HERMANTO (2018) "Sistem informasi Bank Sampah Sukorejo berbasis client server," Jurnal Ilmiah Informatika, $3(1)$.

MUNTOHAR, A. (2020) "Sistem Informasi Data Klien Berbasis Java Pada Kantor Notaris dan PPAT Arif," Edumatic: Jurnal Pendidikan Informatika, 4(2), hal. 58-67. doi: 10.29408/edumatic.v4i2.2515.

PANGESTU, A. \& AFUAN, L. (2021) "Rancang
Bangun Sistem Informasi Pengelolaan Wisata Edukasi Berbasis Website Studi Kasus Kampung Marketer," Jurnal Pendidikan dan Teknologi, 1(2), hal. 45-57.

PRESSMAN, R. S. (2010) Rekayasa Perangkat Lunak Pendekatan Praktisi Edisi 7 (Buku Satu). Andi. doi: 10.1017/CBO9781107415324.004.

PUTRA, H. Y., HANIM, H. \& KARTIKA, A. D. (2020) "Pembangunan Aplikasi Web dan Mobile Sistem Informasi Webinar di Era New Normal Hafid," Jurnal Nasional Teknologi Informasi, 02, hal. 108-115.

SHI, H. $D K K$. (2020) "Radiological findings from 81 patients with COVID-19 pneumonia in Wuhan, China: a descriptive study," The Lancet Infectious Diseases, 20(4), hal. 425434. doi: 10.1016/S1473-3099(20)30086-4.

SOHRABI, C. DKK. (2020) "World Health Organization declares global emergency: A review of the 2019 novel coronavirus (COVID-19)," International Journal of Surgery, 76(February), hal. 71-76. doi: 10.1016/j.ijsu.2020.02.034.

TIAWAN, I. A. \& AFUAN, L. (2020) “Aplikasi Pengelolaan Kerjasama Pembuatan Projek Pada Dinas Komunikasi dan Infromatika Banyumas," Jurnal Teknik Informatika (JUTIF), 1(1), hal. 13-18.

WILDER-SMITH, A. \& FREEDMAN, D. O. (2020) "Isolation, quarantine, social distancing and community containment: Pivotal role for oldstyle public health measures in the novel coronavirus (2019-nCoV) outbreak," Journal of Travel Medicine, 27(2), hal. 1-4. doi: 10.1093/jtm/taaa020. 
Halaman ini sengaja dikosongkan 